\title{
Belediye Sivil Toplum İlişkileri: Yasal - Kurumsal Mevcut Durum ve Plan Vizyonu
}

\author{
The Relations Municipalities And The Civil Society: Current Legal - Institutional Relations And Plan \\ Visions
}

\section{Şerif ÖNER}

Doç. Dr., Ballkesir Üniversitesi, İIBF,

Siyaset Bilimi ve Кати Yönetimi Bölümü,

serifoner@balikesir.edu.tr

https://orcid.org/0000-0002-9446-7394
Makale Başvuru Tarihi: 10.10.2020

Makale Kabul Tarihi: 12.12 .2020

Makale Türü: Araştırma Makalesi

\section{Mustafa Lütfi SEN}

Doç. Dr., Sakarya Üniversitesi, SBF,

Siyaset Bilimi ve Kати Yönetimi Bölümü,

msen@sakarya.edu.tr

https://orcid.org/0000-0001-8763-7909

\section{Anahtar \\ Kelimeler:}

Sivil Toplum

Kuruluşları,

Belediye,

Hemşehri,

Kalkınma Planı,

Keywords:

Non-Governmental

Organizations

(NGOs),

Municipality,

Citizen,

Development Plan,

\section{ÖZET}

Demokrasi, antik Yunandan günümüze kadar toplumların üzerinde en çok tartıştı̆̆ kavramlardan biri olmaya devam etmektedir. Demokrasi, vatandaşların yönetim süreçlerinde belirleyici ve etkin bir özne olmasinın aracı olarak görülmüştür. Bireylerin örgütlü şekilde yönetimde yer alması ile ortaya çıkan sivil toplum, demokrasinin gelişmesine yol açmıştır. Literatürde yerel yönetimler (ve özellikle belediyeler) demokrasinin ve sivil toplumun yansitılacağı en uygun alan olarak görülmektedir. Bu yaklaşımdan hareketle çalışmamızda belediye yönetimleri ile sivil toplum kurulușlarının ilișkileri ele alınmaktadır. Yasal düzenlemelerde yer alan hemşehri hukuku, kent konseyi gibi mekanizmalarda sivil toplumun rolü incelenmektedir. Ancak belediye ile sivil toplum arasındaki ilişkiler açısından yasal düzenlemenin varlı̆̆l tek başına yeterli değildir. Sivil toplumun kapasite, eğitim, mali, personel ve tanınırlık sorunlarının aşılması gereklidir. Bu noktada çalıșma bütünlüğünü sağlamak için 11. Kalkınma Planı ilgili sorun alanlarına ilişkin önerileri açısından ele alınmıştır.

\section{ABSTRACT}

Democracy has been the most debated concepts of societies since Ancient Greece. Democracy has been seen as a tool that enables citizens to determine and effectively participate in the governance process. Civil society has emerged with the participation of institutionally organized citizens in the governance and paved the way for the development of democracy. In the literature, local authorities (and especially municipalities) are seen as the most suitable governance level in which the civil society can participate and the democracy can develop. Based on this approach, this study analyses the relations between municipal authorities and nongovernmental organizations. The study examines the role of civil society in legally regulated mechanisms such as citizen rights and city councils. However, the existence of legal regulation alone is not sufficient for better relations between the municipality and civil society. The capacity, education, financial, personnel and recognition problems of the civil society should be overcome. In order to ensure the integrity of this study, the 11 th Development Plan was adressed with its recommendations for the related problem areas. 


\section{GIRISS}

Tarihsel süreç içinde toplumların ve devletlerin gelişmişlik düzeylerine esas alınan kriterler arasında nüfus, ordu, coğrafi alan, vb. yer almıştır. Özellikle sanayi devrimi sonrasında yaşanan gelişmeler toplumlar ve devletler arasındaki farkı belirleyecek parametreleri ortaya çıkarmıştır. Bu parametreler; üretim, ticaret, teknoloji, bilgi, kentleşme vb.'dir. Günümüzde ise doğru ekonomik ve sosyal göstergelerin yanında; bilgiye erişim, dijital alt yapı, yapay zekâ, e-ticaret altyapısı, ar-ge destekleri, uzay ve hipersonik silah teknolojileri, siber güvenlik, nano teknoloji, vb. parametreler ve/veya ölçütler kalkınma düzeyinin belirlenmesinin yanında devletlerin yerel, ulusal, bölgesel ve küresel etki alanlarında söz sahibi olmalarında belirleyici olmaktadır. Milenyum çağının hâkim perspektifi olarak varlığını sürdürmeye devam edecek gibi görünen "küresel yönetim anlayışı", kimilerine göre küreselleşme ideolojisini daha da pekiştirmek kimilerine göre yerel, bölgesel, ulusal sosyo-kültürel ve dahası ekonomik değerleri dünyanın farklı yerleri için erişilebilir kılmak amacı taşımaktadır. Özellikle ikinci yaklaşım dünya toplumlarının gerek doğal kazanımlarının gerekse tarihsel süreçlerde elde ettikleri birikimlerinin paylaşıma açılmasına yaptı̆̆ katkılar dolayısıyla küreselleşme olgusunu kutsanacak bir boyuta taşımaktadır. Açıkçası konumuz küreselleşme olgusunun toplumlar nezlinde ortaya çıkardığı belki yıkım belki kazanım (her ne ise) olup/olmadığını tartışmak olmamakla birlikte çalışmada; keynezyen politikaların iflası ve/veya miadının doğmasının hem sebebi hem de sonucu olduğunu değerlendirdiğimiz küreselleşmenin kurumsal yönetim süreçlerine etkin ve güçlü şekilde dâhil ettiğini düşündüğümüz sivil toplum kavramına ve örgütlü sivil toplumun yerel ölçekte kendine biçilen rolüne odaklanacağız.

Kent devleti geleneğinde Aristo tarafindan yönetim erkinin karşısında "sitede var olan herşeyin üstündeki toplum" olarak tanımlanan ve şaşırtıcı şekilde farkındalık olarak felsefi metinlere konu olan sivil toplum olgusu ve olguya yönelik ilgi tarihin tüm dönemlerinde devam etmiş görünmektedir. Sivil toplum (civil society); ister toplumsal yaşama ilişkin analitik bakışa konu olsun; ister modernitenin ve demokrasinin olmazsa olmaz ölçütü olarak kabul edilsin; ister yaşamın ekonomik ilişki biçimleriyle açıklandığı dönemdeki karşıtlığ yansıtır şekilde burjuva toplumu ve siyasal otoriteyi meydana getiren kamusal alan olarak açıklansın; ister bireysel hak ve özgürlükler üzerine inşa edilen liberal anlayışın uygulama aparatı olarak görülsün; ister ortak iyiliği üretmek amacıyla devlet tiranlığını engellemenin bir yolu ve despot devlet anlayışına karşı etkili bir panzehir olarak algilansın; ister siyasi hayatı belirleyen bir alan olarak tanımlansın; isterse kolaycı bir retorikle devlet erki dışında bireylerin veya grupların birlikte oluşturdukları (ve bazen devlet karşıtlığını hak eden sertlikte) yapılar olarak adlandırılsın tüm bu yaklaşımlar tarihsel süreçte doğu ve batı toplumları arasındaki gelişmişlik göstergesi olarak da ele alındığına rastladığımız sivil toplum olgusunun yöneten ve yönetilen ilişkilerinde bizce bir tür "yaşayan organizma" tanımını fazlasıyla hak ettiğini göstermektedir.

Sivil toplum, devlet, iş dünyası ve aile arasında yer alan kurumlar, kuruluşlar ve davranışlar kümesini ifade eder. Spesifik olarak bu, birçok farklı türde gönüllü ve kar amacı gütmeyen kuruluşları, hayırsever kurumları, sosyal ve politik hareketleri, sosyal katılım ve katılım biçimlerini, kamusal alanı ve bunlarla ilişkili değerleri ve kültürel kalıpları içermektedir (Kumar, 2008:18). Sivil toplum Devlet ve ekonomik piyasadan ayrı, farklı siyasi katılım ve söylemsel etkileşim yerleri olarak hizmet eden tüm kamusal alanlar olarak tanımlanırken çok çeşitli aktörlerle karakterize edilen bir siyasi ve sosyal eylem ve çekişme alanını da oluşturmaktadır (Gready ve Robins, 2017:958).

Patrimonyal yönetim anlayışının geleneksel kalıplarından sıyrılma sürecini çetin ve uzun sayılabilecek gel-gitler ve siyasi mücadeleler sonrasında kısmen başarabilen ülkemizde sivil toplum çağdaşlarının aksine bir mücadele alanına değil (özellikle vakıf, ahilik, lonca arka planları açısından) daha çok toplumsal paylaşıma ilişkin yaklaşıma/algıya/adanmışlığa işaret etmektedir. Bu bakış açısı bir anlamda sivil toplumun ülkemizdeki varlığını devletin arzuları ve onun tamamlayıcısı çerçevesinde şekillenen bir araç konumuna dönüştürmüştür. Devletin imkân tanıdığı ölçüde sivil toplum var olmuş, yönetsel süreçlerde yer bulmuş ve toplumsal taleplere (devletin koyduğu sınırlar ölçüsünde) sözcülük yapmıştır. Sivil toplumun araçsal niteliği ülkemizde özellikle yerel yönetimlerin yasal ve kurumsal süreçlerinde öne çıkmaktadır.

2019 Şubat ayında TUIKK tarafindan açıklanan verilere göre nüfusumuzun \%92,8'nin il ve ilçe (yani belediye yönetimi kurulması zorunlu olan) yerleşimlerinde yaşıyor olması mevcut yerel yönetimlerin ve nüfus yükü açısından özellikle belediyelerin; yerel hizmet sunumu odaklı sorunlarının aşılmasında; toplumsal memnuniyetin geliştirilmesinde; varolan kaynakların etkin ve yerinde kullanımında; dayanışma ve işbirliği ruhunun geliştirilip yerel toplumsal kesimlere yansıtılmasında ve tüm bunların birlikteliğinde kentsel ve toplumsal refahın "sürdürülebilir" kılınmasında sivil topluma biçilen ve düşen rolün ele alınması önem taşımaktadır. Öte yandan Cumhurbaşkanlığı Hükümet Sistemi (CHS) sonrasındaki ilk Plan olan ve On Birinci 
Kalkınma Planı olarak yayınlanan planın sivil toplum kuruluşlarını yerel ve ulusal ölçekte araçsal nitelikte ele alması ve mevcut yerel yönetim (belediye)-sivil toplum ilişkilerine yönelik şeffaflık, yapabilirlik, kapasite artışı vb. çağdaş yönetsel değerleri sivil toplum kuruluşları açısından öngörmesi dikkat çekmiş ve çalışmanın içeriğine dâhil edilmiştir.

\section{SIVIL TOPLUM KAVRAMSAL ÇERÇEVE}

Üstlendikleri sosyo-kültürel ve ekonomik roller itibariyle kar amacı gütmeden ortak ideal ve hedefler peşinde hareket eden yapılar olarak sivil toplum kuruluşları yerelden ulusala (Keijzer ve Bossuyt, 2020:788) ve artan eğilimler çerçevesinde küresel boyutlara varan bir organizma halini almıştır. Ülkemizde özellikle 1980'ler den itibaren tartışılmaya ve ilgi görmeye başlayan sivil toplum kavramı hedefler, ilişkiler, bağlamsal deneyimler, değerlerin yanında gayri resmi ve resmi yapılarla ilişkili nitelikleri içerir (www.csis.org). Kavram genel olarak; Devlet erkinin etkinlik ve otorite alanı dışındaki sosyo-ekonomik yapıyı açıklamak için kullanılan, kendilerine ait kurallarına göre faaliyet gören özerk nitelikli alan; Devletin kurumsal kontrol veya baskılamasının bulun(a)madığı veya etkin ol(a)madığı alan ölçeğinde, kişi ve/veya grupların kamu erkinden izin alma ihtiyacı duymadan adli ve idari soruşturma tedirginliği olmadan, ekonomik baskılardan arınmış olarak davranabildikleri, sosyal, kültürel vb. faaliyetlerde düzenleyebildikleri, gönüllü aynı zamanda rızaya dayalı ilişkilerin oluşturulduğu toplum ve kamu erki dışındaki kuruluşların bütünü olarak değerlendirilmektedir (Yılmaz, 1997:86; İbrahim, 1997:38; Atar, 1997:98). Özellikle yirminci yüzyılın yıkıcı mücadele dönemlerinden sonra sivil toplum, güçlü biçimde demokratik geçiş için baskı oluşturma ve onu tamamlamaya itme konusunda kilit rol oynamış (www.ukessays.com) ve bu rolünü halen sürdürmektedir. Sivil toplum açıklamalarında kamu erki dışındaki yapılar ele alınmakta kişi ve/veya kişi gruplarınca oluşturulan söz konusu kurumların baskı görmeden her konuda etkin oldukları işleyiş̧ olarak kabul edilmektedir (Öner, 2001:59).

Sivil toplum (civil society) olgusunun kökeni Antik Yunan'da Aristoteles'e kadar uzanmakla birlikte (Aslan, 2010:190) kavram, 18. yüzyılda düzenli toplumsal yaşam arayışlarına cevap verecek analitik araç olarak kabul edilmiştir. Bu anlamda sivil toplum, modernitenin hem sonucu hem de ön koşulu olarak (Sarıbay, 1995:15) görülmektedir. Sivil toplum kavramı, Aristo tarafindan "diğer toplumları kapsayan ve onlara egemen olan sitede var olan her şeyin üstündeki toplum" (Öner, 2000:141), olarak kullanılmıştır. Doğu ve Batı toplumları arasındaki kadim tartışma alanlarından birini oluşturan sivil toplum olgusu Batı coğrafyasında ortaya çıkan ve siyasal düşünce akımlarını etkisi altına alan ekonomik gelişmeler ile eş zamanlı olarak tartışılmaya ve yönetsel sürece eklemlenmeye çalışılmıştır.

Ekonomik ilişki biçimlerinin yansıması olarak kavram "burjuva toplumu" (San, 1994:6) olarak nitelenirken, toplum-devlet arasında ortaya çıkan ilişki biçimlerine yönelik temel yaklaşımlar ortaya koyan Hobbes ve Locke gibi sözleşmeci düşünürler tarafından "siyasal otoriteyi meydana getiren kamusal alan" (Çaha, 1997:29) anlamında kullanılmıştır. Hobbes teorisinde, sivil toplumu doğa halinin karşıtı olarak ele alır. Ona göre, sivil ya da siyasi toplum ancak doğa halinden çıkmakla varlık kazanabilir (Gönenç, 2001:14). Modern burjuva toplumunun çağdaşı olan Locke, bu yapının sosyo-ekonomik ve siyasal isteklerinin karşılanmasına altyapı oluşturacak olan bireysel özgürlüklerin genişletilmesinin yanında devletin aşırı gücünün sınırlandırılmasını önermek suretiyle zorba/despot devlete karşı sivil toplumun etki alanını yaygınlaştırmayı savunmuştur (Aslan, 2010:194).

Devlet ile sivil toplum arasında ilk ayrımı yapan Hegel ise sivil toplumu; devlet ve aile arasında konumlanan sosyal alan, çalışmaları normlarca belirlenen bu özelliği ile devlet erkiyle doğrudan ve organik ilişkili olmayan kurumlardan meydana gelen yapı olarak ele almıştır (Gönenç, 2001:8). Hegel devlet ve sivil topluma meşru bir hareket alanı bırakmakla birlikte devleti daha üstün saymayı tercih etmesi ile (Yenişehirlioğlu, 1995:1920) ön plan çıkmıştır. Hegel'in önceliği devlete veren yaklaşımının aksine Karl Marx sivil toplumu; siyasi hayat üzerinde hâkim bir alan olarak tanımlamıştır. Siyasal toplum-sivil toplum ayrımı yapmayan aksine "sivil toplum ile siyasal toplumun aynı düzlemde yer aldığını" (Halifeoğlu ve Yetiş, 2013:174) ileri süren Marx'a göre sivil toplum ağırlıklı olarak ekonomik alana tekabül eden bir anlam kazanmış ve 18. yüzyıl Avrupa'sında burjuvazi ile gelişmiştir (Öner, 2000:141). Ayrıca Marx'ın yaklaşımından hareketle kapsayıcı bir bakış açısıyla sivil toplum olgusunun "küresel" bir çağrışım içerdiği savunulmaktadır. Bu çerçevede Marx'ın "kapitalizm eğilim olarak her zaman küresel olduğundan, sivil toplum da doğası gereği küreseldi", görüşünden hareketle kapitalizmde piyasa ve ekonomik ilişkilerin her zaman sivil toplumun kalbinde yer aldığı Marksist kavramsal analizde böyle bir anlayışın bulunduğuna vurgu yapılmaktadır (Kumar, 2008:15-16).

Gönüllülük düşünceleri ve kolektif eylem, sivil toplum için çok önemli olan demokrasinin temelini oluşturmaktadır. Sivil toplum anlam olarak çoğulcudur. Belki de terimin en derin ve kalıcı tanımı, sivil toplumu, 
gönüllülük temelinde kurulan eşitler arasında bir sözleşme olarak tanımlayan tanımdır (www.ukessays.com). Siyasiliğin devletin tekelinde olmadığını savunan Tocqueville, Amerikan toplumu örneğinde somutlaşan ve siyasi toplumu şekillendiren bir sivil toplum açıklaması yapmaktadır (Gönenç, 2001:8). Bu çerçevede Tocqueville, ortak eylem fikrini, ortak iyiliği üretmek amacıyla devlet tiranlığını engellemenin bir yolu olarak ortaya koyarak kavramı daha da genişletmekte ve sivil toplumu ortak bir iyiliğin teslimi için gönüllü çaba ile bir özyönetim modeli olarak tanıtmaktadır (www.ukessays.com). Gramsci ise, sivil toplumun, ekonomik ilişkilerden ibaret bir alan olmadığını vurgulayarak, sivil toplum alanındaki meselelerin aslında siyasi olduğu saptamasını yaparak ve bunu "devlet = siyasi toplum + sivil toplum" (Gönenç, 2001:8) şeklinde formüle etmiştir. Böylelikle günümüz yönetsel ilişkilerinin bir unsuru olan sivil toplum kavramı bu teoriler yoluyla biçimlendirilmiştir. Öte yandan sivil toplum kuruluşları yönetişimde çok önemli rol(ler) oynamaktadır. Birincisi, iyi toplumun savunucuları olarak, demokratik ilkeleri teşvik etmeye ve demokratik olarak seçilmiş hükümetleri savunmaya yardımcı olurlar. İkincisi, ulusal kaynakların sağduyulu ve etkin kullanımını sağlamak için bir tür bekçi olarak hareket ederler. Üçüncü olarak, iyi yönetişimle ilgili konularda halkın bilinçlendirilmesine ve iyi bilgilendirilmiş bir toplumun geliştirilmesine yardımcı olurlar (www.ukessays.com).

Yukarıda ele almaya çalıştığımız biçimiyle tarihsel süreçte çok sayıda siyaset bilimci, akademisyen ve uygulayıcı, araştırma ve deneyimlerine dayanarak sivil toplum tanımları önermişlerdir. Günümüz Avrupa ölçeğinde kabul gören bu tanımlardan birine göre sivil toplum; aile, devlet ve pazar dışındaki arena olarak düşünülen sivil unsurlar tarafından oluşturulmuş, bireysel ve kolektif eylemler, kuruluşlar ve kurumlar tarafından ortak çıkarları geliştirmek için yaratılmış olan yapılardır. Bununla birlikte, sivil toplum tanımının mevcut evrimini, nüanslarını ve artan çeşitliliğini temsil etmesi kritik öneme sahiptir. Mevcut biçimini yakalayan bir perspektifte sivil toplum kavramı (www.csis.org);

\section{"Devlet, iş dünyası ve aile arasındaki alanda var olan, yerli ve dışsal bilgiler, değerler, gelenekler ve işbirliğini teşvik etmek ve vatandaşlar arasında belirli hedeflere ulaşılmasıinı sağlamak için inşa edilen, örgütlü ve organik sosyal ve kültürel ilişkilerin bir ekosistemi ve diğer paydaşlardan oluşan kurumsal yapılar a $\breve{g l} "$,}

olarak tanımlanmaktadır. Öte yandan sivil toplum olgusu, toplumun doğrudan kendini ilgilendiren konulara ilişkin kararları alabildiği bir mekanizma olarak da ele alınmaktadır. Bu yaklaşımda sivil toplumun ayırt edici özelliği, bireylerin başta ekonomi olmak üzere önem arz eden tüm konulardaki kararları hür bir şekilde alabildikleri sosyo-ekonomik düzen (Üstünel, 1991:49) olarak açıklanmaktadır.

Sivil toplum hedefler, ilişkiler, bağlamsal deneyimler, değerler ve gayri resmi ve resmi yapılarla ilişkili nitelikleri içermekle (www.csis.org) birlikte sivil toplum olgusunun en belirgin niteliği kamu aygitına göre konumudur. Bu çerçevede sivil toplum kuruluşları devlet erki dışında bireylerin ve/veya grupların bir araya gelerek oluşturdukları yapılardır. Genel olarak sivil toplum kuruluşları; "belirli mekân ve zamanda, bilgiye dayanarak teşhis edilen ihtiyaçları gidermeyi hedefleyen, kar amacı olmaksızın çalışan ve bu haliyle kamu yönetiminde yer alan kuruluşlar olarak çıkan ve talepler ekseninde örgütlenmiş yapılar olarak" (Öner, 2001:60) tanımlanabilir. Burada sivil toplum kuruluşu ifadesi geniş bir kavramsal seti kapsamaktadır ve devlet dışı, kar amacı gütmeyen aktörlerin sosyal hareket örgütleri, inanç örgütleri, sendikalar ve düşünce kuruluşlarının hepsi aynı şemsiyenin altında toplanmaktadır (Kalm vd., 2019:502).

Sivil toplum kuruluşları demokratik sistem içinde devlet aygıtı dışında faaliyet göstermekle birlikte kendi amaçları doğrultusunda yerel, bölgesel ve ulusal düzeyde siyasal kararları etkilemeye de çalışırlar ve bu yönüyle bask1 grubu olma özelliğine de sahiptirler (Öner, 2000:134). Bask1 grubu kavramının; "belirli bir topluluğun çıkarlarını savunmak veya taleplerini siyasal otoritelere iletmek veya ifade etmek suretiyle kamu siyasasını etkilemek için var olan grup" (Kalaycığlu, 1984:317) tanımlandığını düşündüğümüzde her sivil toplum kuruluşunun bir baskı grubu niteliği taşıyabilme kapasitesinin örgütlü olma kriterinin sağlanması ile mümkün olabileceği ve bu kriterin sağlanması sonrasında ise sivil toplum kuruluşundan baskı grubuna dönüşmenin göreceli ve konjonktürel olabileceği söylenebilir. Bu haliyle pek çok sivil toplum kuruluşu çıkar grubu olma perspektifi içinde sıkışıp kalmaktadırlar. Kaldı ki çıkar gruplarının kendileri ve temsil ettikleri kesimlerin ihtiyaçlarını karşılamak amacıyla "kamu yönetimlerini etkilemeye çalışmaları" (Richardson, 1993:7) bir sorun olarak görülmeye devam etmektedir.

Yönetsel süreçlerdeki rolleri açısından sivil toplum kuruluşlarının çıkar grubundan baskı grubuna evrilmeleri yönünde meydana gelen tartışmalar ve/veya yeni rol tanımlamaları yapılmadan yeni bir olgu olan küreselleşme ve sivil toplum kuruluşu ilişkisi konuşulmaya başlanmıştır. Bu çerçevede son yirmi yılda dünya siyasetindeki ana eğilim, bir yandan uluslararası kuruluşlar ile diğer küresel yönetim kurumları türleri arasında ve diğer yandan sivil toplum kuruluşları arasındaki etkileşimin yoğunlaşması olmuştur. Bu eğilim, STK'ların küresel 
yönetişimin demokratik niteliklerini iyileştirme potansiyelleri ile ilgili bilimsel bir tartışmaya yol açmıştır. Sivil toplum aktörleri, kendileri için küresel yönetişim düzenlemelerinde savunuculuk çabalarını giderek daha fazla yönlendirmiş olmaları onları bu nedenle hedeflerini daha önce belirttikleri ulusal ve yerel yönetimlerle ilgili endişelerden uzaklaştırmaktadır (Kalm vd, 2019:499-500). Sivil toplum olgusuna ilişkin tarihsel süreç içinde önemli değişiklikler yaşanmış ve farklı dönemlerde, toplum temelli kuruluşlar, işçi veya işçi sendikaları, meslek kuruluşları ve sivil toplum kuruluşları belirgin şekilde öne çıkmış olmakla birlikte sivil toplumu tanımlamak basit bir iş değildir. Ancak, genel olarak devlet ile birey arasındaki politik alemi işgal etmeleri ve sosyal tabakalardaki diğer grupların yanı sıra alt sosyal grupları da kapsamalarının yanında (www.ukessays.com) son zamanlarda, sivil toplumun farklı tipolojilerine ilişkin ayrımlara gidilmektedir (www.csis.org). Sivil toplum kuruluşları inanç temelli örgütleri ve organize bir yapı ve misyonu olan toplum temelli örgütleri içermektedir. Genellikle, tescilli kurum ve gruplar; organize olabilen, ancak mutlaka fiziksel, yasal veya finansal yapılara sahip olmayan gruplar ve etkinlikler; toplu eylem ve/veya kimliğin sosyal hareketleri; işçileri temsil eden işçi sendikaları ve işçi örgütleri; sosyal ve çevresel yaklaşımlar için yenilikçi ve/veya pazar odaklı yaklaşımlar kullanan sosyal girişimciler olarak ayrışmaktadırlar.

Türkiye açısından politik ve yönetsel karar alma süreçlerinin etkin ana unsuru olmaları konusunda istenilen düzeye gelinmemiş olmasına karşın sivil toplum kuruluşlarının özellikle yerel yönetim mekanizmalarında (yine istenilen düzeyde olmamakla birlikte) yer aldıkları görülmektedir. Aşağıdaki bölümde ülkemizdeki yerel yönetim geleneğine çerçevesinde şekillenen sivil toplum ilişkileri ile hizmet ürettikleri nüfus açısından diğer yerel yönetim kurumları arasında öne çıkan belediye yönetimlerinin sivil toplum kuruluşlarına ilişkin mevcut yasal ve kurumsal arka plan ele alınmaya çalışılmaktadır.

\section{YEREL YÖNETIM GELENEĞİ VE SIVIIL TOPLUM İLIŞKİLERI}

Sivil toplum büyük ölçüde yerel bir çağrışıma sahip olurken genellikle devletler ve toplumlar içindeki kamusal alanla ilişkili olarak algılanmıştır (Kumar, 2008:17). Ancak sivil topluma ilişkin bu genel değerlendirmenin ülkemiz açısından öncelikle kabul edilen bir yaklaşım olmadığı görülmektedir. Bu çerçevede örneğin Tanzimat dönemi sonrasında ülkemiz sınırları içinde kurumsallaşmaya başlayan yerel yönetimler, kuruluş amacı doğrultusunda öncelikle yerel nitelikli hizmetlerin ve ihtiyaçların karşılanmasına odaklanmışlardır. Cumhuriyetin ilanı sonrasında da öncelikle aynı amaç doğrultusunda konumlandırılmaya çalışılmışlardır.

20. yüzyıl içinde tanık olunan küresel ölçekli sosyo-ekonomik ve yönetimsel anlayış ve uygulama değişiklikleri kuşkusuz ülkemizin yerel yönetimlerini düşünsel, yasal ve işleyiş açısından etkilemiş̧ir. Söz konusu değişimin temel unsurları içinde demokrasinin tabana yayılması ve seçim dönemleri dışında da işlevsel kılınmasına yönelik olarak ortaya konulan yeni kamu yönetimi anlayışı, katılımcı demokrasi, yönetişim, iyi yönetişim vb. modeller artan kentsel sorunlara ilişkin çözüm arayışlarının sığındığı bazen de tercih etmek zorunda kaldığ 1 yönetimsel bir gereklilik olarak ortaya çıkmıştır. Bu çerçevede katılımcı demokrasi uygulama pratiklerinin değişmez temel aracı olarak sivil toplum kuruluşları öne çıkmış ve bu yapıların (konumuz açısından) yerel yönetim yapıları ile ortaklık ve/veya işbirliği perspektifleri üzerinde yoğunlaşılmaya çeşitli araçsal model arayış ve girişimlerine rastlanılmıştır.

Çalışmamızın bu kısmında öncelikle (Osmanlı dönemindeki birikimleri yadsımadan) Cumhuriyet dönemi yerel yönetim geleneğinin oluşumuna ilişkin perspektif ortaya koyduktan sonra yönetsel ilişkiler açısından salt bir "araçsallaştırılma" olarak değerlendirdiğimiz sivil toplum-yerel yönetim ilişkilerini ele almaya çalışacağız.

\subsection{Türkiye'de Cumhuriyet Dönemi Yerel Yönetim Geleneğinin Oluşumu}

Geçmiş dönemler açısından kent yaşamına ait birincil ihtiyaçların yerel kurumlar (vakıf, lonca,) aracılığıyla karşılanması ihtiyaca cevap verirken günümüz koşullarında kentsel ihtiyaçların salt karşılanması değil, optimal biçimde (etkin ve zamanında vb.) yerine getirilmesi önem taşımaktadır. Günün koşulları açısından kentsel ihtiyaçların karşılanması bakımından başarılı bulunmamakla birlikte Tanzimat sonrasında Osmanlı'da oluşturulan belediye teşkilatları Cumhuriyetin ilk dönemlerine kadar var olmuşlardır. Genel kabullere göre Cumhuriyet yönetimi Osmanlı'dan yadsınmayacak belediye yönetimine ilişkin yönetsel kültür ve araçsal kurumlar devralmış bunları çağın yönetsel gereklerine adapte olacak şekilde geliştirmiştir. Cumhuriyetle birlikte, artan ve karmaşıklaşmaya başlayan kent ihtiyaçlarını karşılamak; demokrasiyi yerele indirgemek; vatandaş ve kurum katılımını sağlamak amaçlarına yönelik olarak belediye yönetimlerinde hukuki ve yapısal biz dizi önemli değişikliğe gidilmiştir. 
Nadaroğlu (1998:3) tarafından "Devlet sinırları içinde yerleşmiş irili ufaklı insan topluluklarının ortak ve yerel nitelikteki ihtiyaçlarını karşılamak amacıyla belli bir hukuk düzeni içinde oluşturulan anayasal kuruluşlar", olarak tanımlanan yerel yönetimler Tanzimat sonrasında (önemli bir deneyim olan İstanbul Şehremaneti örneği ile) yönetim yapımız içinde yer almıştır. Anayasal tarihimiz içinde 1876 Kanun-i Esasi'deki yerel yönetimlere ilişkin yer alan temel ilkeler bazı değişik uygulama örnekleri ile birlikte uygulamada kalmaya devam etmiştir (Keleş ve Yavuz, 1989:44). 1876 Kanunu-i Esasisinin 112. maddesinde belediye işlerinin (İstanbul ve taşrada) seçimle oluşturulacak meclislerce yerine getirilmesi, 108. madde de, il yönetiminde yetki genişliği ve görev ayrımı ilkelerinin uygulanması düzenlenmiştir (Öner, 2006:21-22). Kurtuluş savaşının sürdüğü bir dönemde hazırlanan 1921 Anayasasında; yerinden yönetim ilkesi benimsenmiş, yerel yönetimlerle ilgili dönemin modern normlarına benzer düzenlemelere gidilmiş, yerel meclislerin yerel halk tarafından belirleneceği hükme bağlanmışken Türkiye Cumhuriyeti'nin ilk resmi Anayasası olan 1924 Anayasası'nda yerel yönetimler konusunda dikkate değer düzenlemeler yapıl(a)mamıştır (Öner, 1998:3720). 1961 Anayasasında yerel yönetimler konusunda diğer anayasalardan farklı olarak "hizmet yerinden yönetim" ilkesi yer almış, "adem- $i$ merkeziyet" anayasal nitelik kazanmış ve 116. madde de mahalli idareler düzenlenmiştir (Öner, 2006:23). 1982 Anayasasında ise 123. madde ile "idarenin kuruluş ve görevleri merkezden yönetim ve yerinden yönetim esaslarına dayanır", hükmü ve yetki genişliği ilkesi benimsenmiştir. 127. madde ile ayrıntılı düzenleme yapılmış ve mahalli idareler; "Il, belediye veya köy halkının mahalli müşterek ihtiyaçlarını karşılamak üzere kurulan tüzel kişiler" olarak tanımlanmış; aynı madde içinde yer alan "Kanunla büyük yerleşim merkezleri için özel yönetim biçimleri oluşturulabilir", hükmü uyarınca 1984 yılında Büyükşehir Belediyeleri kurulmuştur.

Şekil 1. Türkiye'de Yerel Yönetim Yapılanması

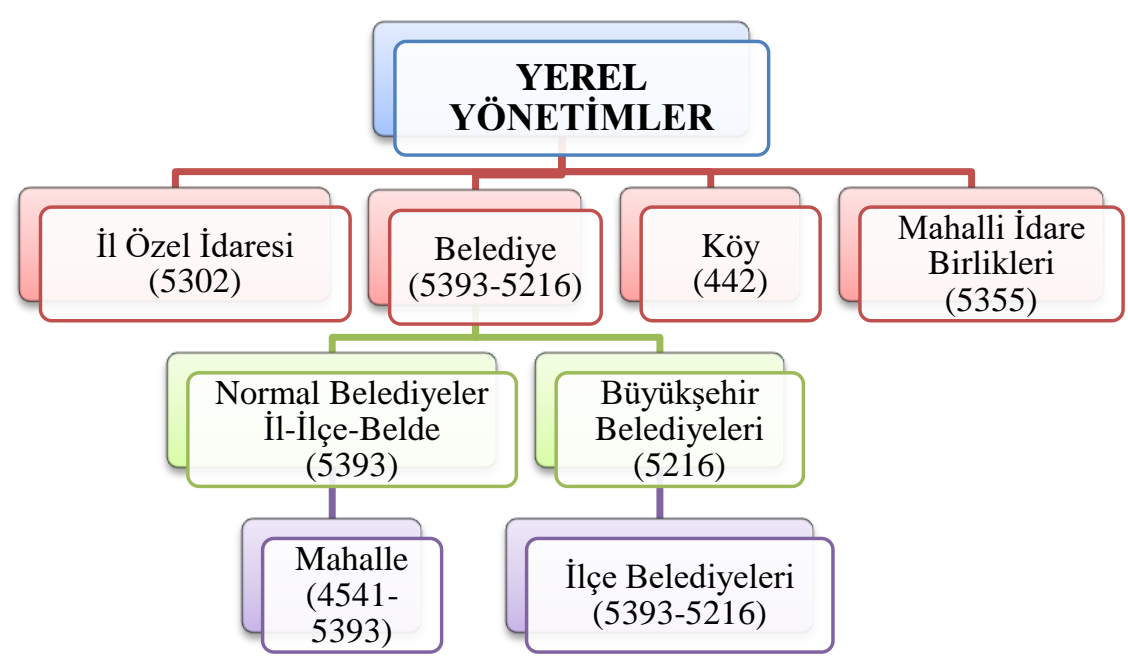

Kaynak: Keleş vd., 2009:7.

Milenyuma giriş ile birlikte ülkemizde yerel yönetim işleyişi konusundaki temel sorunların aşılmasına yönelik öncelikle Büyükşehir Belediyesi Kanununda büyük oranda güncelleme yapılmıştır. Yürürlüğe giren 5216 sayılı Büyükşehir Kanunu (23.07.2004) ile 1984'den itibaren uygulanan 3030 sayılı Büyükşehir Kanununda değişiklikler yapılmıştır. Benzer şekilde Cumhuriyet döneminin ilk belediye mevzuatı olan 1580 sayılı Belediye Kanunu yerine 5393 sayılı Belediye Kanunu (13.07.2005) yürürlüğe girmiştir. İl Özel İdareleri’ne ilişkin 3360 sayılı Kanun yerine 5302 sayılı İl Özel İdaresi Kanunu (04.03. 2005) uygulamaya konulmuş, Mahalli İdare Birliklerine ilişkin 5355 sayılı Kanun (11.06.2005) yürürlüğe konulmuştur (Tablo1).

Tablo 1. Güncel Temel Mevzuat

\begin{tabular}{|c|c|c|c|c|}
\hline Kanun Adı & Kanun No & TBMM Kabul & R.G. Tarihi & R.G. Sayısı \\
\hline \multirow{2}{*}{ Büyükşehir Belediyesi Kanunu } & 5216 & 10.07 .2004 & 23.07 .2004 & 25531 \\
\cline { 2 - 5 } & 6360 & 12.11 .2012 & 06.12 .2012 & 28489 \\
\hline Belediye Kanunu & 5393 & 03.07 .2005 & 13.07 .2005 & 25874 \\
\hline İl Özel İdaresi Kanunu & 5302 & 22.02 .2005 & 04.03 .2005 & 25745 \\
\hline Mahalli İdare Birlik. Kanunu & 5355 & 25.05 .2005 & 11.06 .2005 & 25842 \\
\hline Köy Kanunu & 442 & 18.03 .1924 & 07.04 .1924 & 68 \\
\hline
\end{tabular}


Özellikle büyükşehir nüfusunda meydana gelen sayısal artışı ve ortaya çıkan sorunların aşılmasına yönelik olarak ilk akla gelen yöntem olarak ortaya çıkan kurumsal ve yapısal arayışların yansıması olarak 2012 yılında Büyükşsehir reformuna gerçekleştirilmiş ve 6360 sayılı "Onüç İlde Büyükşsehir Belediyesi ve Yirmi altı Illçe Kurulması Ille Bazı Kanun ve Kanun Hükmünde Kararnamelerde Değişiklik Yapılmasına Dair Kanun" (06.12.2012) yürürlüğe girmiştir. 6360 ile toplam nüfusu 750.000 'den fazla olan il yönetimlerinin belediye statülerinin büyükşehir olarak güncellenmesiyle 13 ilde daha büyükşehir belediyesi kurulmuştur. $\mathrm{Bu}$ iller; Aydın, Balıkesir, Denizli, Hatay, Malatya, Manisa, Kahramanmaraş, Mardin, Muğla, Tekirdağ, Trabzon, Şanlıurfa ve Van'dır. Daha sonra müstakil bir düzenleme olan 6447 sayılı kanunla (22 Mart 2013) Ordu ilinde büyükşehir belediyesi kurulmuş ve bugün itibariyle ülkemizdeki büyükşehir belediyesi sayısı 30'a çıkmıştır.

6360 ve 6447 sayılı kanunlar ile 30 il özel idaresi, 16.082’i Köy tüzel kişiliği, 1591 belde belediyesi ile Büyükşehirlerdeki bucak teşkilatları kapatılmıştır. Ülke nüfusumuzun \%76,5'i (56.525.820 kişi) büyükşehir sınırlarında yaşamaya başlamış ve Türkiye topraklarımızın \%51,5'i $\left(401.447 \mathrm{~km}^{2}\right)$ büyükşehir alanı haline dönüşmüştür (Tandırcıoğlu ve Öner, 2014:254). TUİK'in Şubat 2020 verilere göre Ülkemizde 2018 y1lında $\% 92,3$ olan il ve ilçe merkezlerinde yaşayanların oranı 2019 yılında $\% 92,8$ olurken; belde ve köylerde yaşayanların oranı \%7,7'den \% 7,2'ye düşmüştür (www.tuik.gov.tr).

\subsection{Belediye ve Sivil Toplum İlișkilerinin Kurumsal İșleyișe Yansımaları}

Sivil toplumun birey ile devlet arasında arabuluculuk yapan bir dizi organizasyon ve kurum ve sosyal ilişkilerin alanlarını içeriyor olması (Gready ve Robins, 2017:958) kurumsal yapıların işleyişine katılım noktasında sivil toplum kuruluşlarını motive eden bir unsur olmuştur. Anayasal düzeydeki belirlemeye göre ülkemizde belde halkının yerel ve ortak nitelikli ihtiyaçlarının karşılanması amacıyla belediye, özel idare ve köy yönetimleri (hatta mahalli idare birlikleri) oluşturulmuştur. 6360 sayılı Kanunla gerçekleşen son düzenlemeler ile birlikte gerek Türkiye nüfusunun \%76,5'inin büyükşehir belediye sınırları içinde yaşamakta olması, gerekse toplam ülke nüfusunun il ve ilçe merkezlerinde yaşayanların oranının \%92,8'a ulaşmış bulunması; artan hizmet talebi ve çeşitliliği, merkezi idare ile olan ilişkiler, küresel yönetsel anlayışın yansımaları, bütçe rakamları vb. yanı sıra siyasi tartışma merkezindeki ağırlıklarının göreceli artışı gibi pek çok nedene bağlı olarak belediye yönetimlerine olan ilgiyi artırmakta ve öne çıkarmaktadır. Benzer gerekçeler çerçevesinde tarihsel süreç içinde çeşitli biçim ve fonksiyonlar icra ederek var olan bireysel insiyatif özneli sivil toplum kuruluşları ile ilişkileri açısından belediye yönetimleri özel bir incelemeyi, durum tespitini ve projeksiyonu gerektirmektedir.

Belediye yönetimlerinin sivil toplum kuruluşları ile kurumsal ilişkilerinin yasal düzenlemeler çerçevesinde başlıca üç başlıkta toplanmış olduğu görülmektedir: Hemşehri Hukuku, Kent Konseyi, Gönüllü Katılım.

\subsubsection{Hemşehri Hukuku ve Hemşehri Odaklı Yönetimin Kurumsallaşması}

Ruşen Keleş'in ifadesi ile kenttaşlık (hemşehri hukuku) denildiği zaman ilk akla gelen, kentttaşlık kurumunun dayandığı tüm hukuk kurallarıdır. Bunun yanında kentte yaşamakta olan kişinin (kenttaşın) sahip olduğu haklarda kenttaş hukukunun bir başka perspektifini oluşturur (Keleş ve Mengi, 2017:83). Bu çerçevede 5393 sayılı Belediye Kanununun Hemşehri Hukuku başlıklı 13. maddesine göre; "Herkes, ikamet ettiği beldenin hemşehrisidir. Hemşehrilerin, Belediye karar ve hizmetlerine katılma; Belediye faaliyetleri hakkında bilgilenme ve Belediye idaresinin yardımlarından yararlanma hakları vardır". İlgili madde bağlamında özellikle seçim döneminde oy verme işlevinin/hakkının yapısal alanı içine sıkıştırılan "yerel demokrasi ve katılım" anlayışını aşmayı hedefler biçimde, Belediyelerin sosyo-kültürel alandaki görevlerini yerine gerirken üniversiteler, meslek kuruluşları, sendikalar ve sivil toplum kuruluşları ile işbirliği yapmaları düzenlenmiştir.

5393 sayılı Belediye Kanunu ile hemşehri tanımı kanuni çerçevede önemli bir değişikliğe uğramış ve yeni düzenlemeye göre herkesin ikamet ettiği beldenin hemşehrisi olduğu hükme bağlanmıştır. Uygulamadan kaldırılan 1930 tarih ve 1580 sayılı Belediye Kanunu'nda; her Türk, nüfus kütüğ̈̈ne yerli olarak yazıldığg beldenin hemşerisi olarak tanımlanmış ayrıca hemşerilerin belediye işlerinde reye, intihaba, belediye idaresine iştirake ve belde idaresinin devamlı yardımlarından istifadeye hakları olduğu güvence altına alınmıştı (md.13). 5393 sayı1ı Belediye Kanunu ile temelde hemşehri kavramı için öngörülen nitelik değiştirilmiştir. 1580'e göre, vatandaşlar nüfus kütügüne kayıtlı olunan yerin hemşehrisi olarak kabul edilirken 5393 sayılı Kanunla ikamet edilen belde, hemşerilik ilişkisi açısından temel kriter olarak alınmıştır. Kanunda hemşehrilerin hakları üç başlık altında toplanmıştır. Buna göre tüm hemşehrilerin: belediye karar ve hizmetlerine katılma, belediye faaliyetleri hakkında bilgilenme, belediyenin yardımlarından yararlanma hakları bulunmaktadır (md.13/1). 
Günümüz demokrasi perspektifleri açısından yerel ölçekte yapılan seçim sürecini demokrasinin varlığı için yeterli görmek zordur. Salt seçim eksenli demokrasi uygulamalarının yanı sıra kişi ve kurumların yönetim süreçlerine katılımlarını sağlayacak modeller geliştirilmiştir. Bu konuda toplumsal kesimlerde ve yönetim erkinde yeterli olmamakla birlikte zihinsel dönüşüm yaşanmış ve önemli gelişmeler kaydedilmiştir. Buna karşın, Belediye Kanununda yönetsel süreçlere katılım daha çok danışma niteliği ile kısıtlanmıştır (Keleş vd., 2009:16; Öner, 2006:45). Kanunun 3. maddesinde belediye; "belde sakinlerinin mahallî müşterek nitelikteki ihtiyaçlarını karşılamak üzere kurulan ve karar organı seçmenler tarafindan seçilerek oluşturulan, idarî ve malî özerkliğe sahip kamu tüzel kişisi" olarak tanımlanmıştır. Bu tanıma uygun işleyiş gerçekleştirmesini sağlamaya yönelik olarak sivil toplum kuruluşlarının belediye karar süreçlerine katılımını sağlayacak bir modelin uygulanması gereği açıktır.

Belediye Kanununda, yerel halkın özelliklerinin dikkate alınmasına yönelik temel ilke olarak 14. madde de; "belediye hizmetlerinin vatandaşlara en yakın yerlerde ve en uygun yöntemlerle sunulması", hükme bağlanmıştır. Bu yaklaşım hemşehri odaklı bir yönetimin kurumsallaşması adına atılmış önemli bir adımdır (Keleş vd., 2009:16-17). Belediye Kanununda hemşehri odaklı yönetimin kurumsallaşmasına yönelik olarak içinde sivil toplum kuruluşlarının da bulunduğu yerel unsurların katılımına yönelik düzenlemeleri kısaca şu şekilde derleyebiliriz (Öner, 2006:46);

- Belediye meclis toplantıları açıktır ve yerel halk ve sivil toplum kuruluşları dinleyici olarak katılabilirler

- Sivil toplum kuruluşları meclis ihtisas komisyonu toplantılarında görüş bildirebilecekler

- Stratejik plan ve acil durum planları sivil toplum kuruluşlarının da katılımı ile hazırlanacaktır

- Belediyeler; sağlık, eğitim, çevre vb., hizmetlerin gerçekleştirilmesinde gönüllü kişilerin katılımına ilişkin programlar uygulayacaklardır.

Belediye Kanununa göre hemşehri odaklı yönetimin kurumsallaşmasına yönelik yasal düzenlemelerin tek başına hemşehrilerin ve sivil toplum kuruluşlarının belediye kararlarına katılma hakkının tam olarak sağlanması anlamına gelmemekte olduğu açıktır. Bu çerçevede ilgili toplumsal kesimlerin (özel anlamda sivil toplum kuruluşlarının) belediye yönetim süreçlerine ve kentsel hizmetlere ilişkin belirleyici, destekleyici, bizzat rol alıcı pozisyona gelmelerine yönelik yasal tedbirler başta olmak üzere diğer kolaylaştıcı yerine göre teşvik edici altyapı ve arka planların düşünsel ve kurumsal ölçekte geliştirilmesi gerekmektedir. Kısaca sivil toplum kuruluşlarının kentsel hizmet ve hemşehrilik hukuku noktasında yapabilirlik düzeylerinin belirleyici olduğuna ilişkin farkındalığın tesisi önem kazanmaktadır. Çalışmamızın aşağıda yer alan "onbirinci kalkınma planı ve sivil toplum perspektifi" başlığında sivil toplum kuruluşlarının yapabilirlik düzeylerinin geliştirilmesi yönünde planda yer alan öngörüler ve tedbirler ele alınacaktır.

\subsubsection{Kent Konseyi}

Katılımcı demokrasi açısından önem taşıyan yerel ölçekte görüş bildirme ve buna esas teşkil edecek araştırmaları yapmakla görevlendirilen kurumsal yapılar olan yerel gündem 21 meclisleri 5393 sayılı Belediye Kanunu ile hukuki nitelik kazanmışlar ve kent konseyi olarak yapılandırılmışlardır. Geçmiş dönemde Türkiye'de YG-21 adıyla kurulan kent konseyleri, toplumsal kesimleri temsil eden örgütlü grupların görüş oluşturma süreçlerine katılmasını sağlamak ve bu süreçlerin geliştirilmesi için kent ölçeğinde danışma mekanizmaları oluşturmak amacıyla yapılandırılmıştır. Bu çerçevede kent konseyi modeli ile kent ölçeğinde sivil toplum kuruluşları, meslek odaları, özel sektör kuruluşları ve muhtarlıklar, kamu kurum ve kuruluş temsilcileri gibi çeşitli kişi ve kurumlar bir araya getirilmektedir. Seçilmiş yerel yönetim organlarının çalışmalarına halk katılımını ve denetimini sağlamak için düzenlenen kent konseyi modeli ile yerel demokrasinin ve katılımın kurumsallaştırılması, tabana yayılmasına yönelik açınım getirilmektedir. Ayrıca Belediye Kanunundaki kent konseyi düzenlemesi ile Özerklik Şartında öngörülen "vatandaşlardan oluşan meclisler" önerisi (md. 3/2) ihdas edilmektedir. Özerklik Şartında özerkliğin, yerel makamlar (meclisler veya kurullar) tarafından kullanılacağı ancak bu durumun vatandaşlardan oluşan meclislere, referandumlara veya vatandaşların doğrudan katılımına olanak veren öteki yöntemlere başvurulabilmesini hiçbir şekilde etkilemeyeceği hükme bağlanmıştır (Öner, 2006:242). İçişleri Bakanlığı tarafından 5272 sayılı kanuna yönelik olarak hazırlanan kent konseyi yönetmelik taslağında kent konseyi;

"merkezi yönetimi, yerel yönetimi ve sivil toplumu ortaklık anlayışıyla ve hemşerilik hukuku çerçevesinde buluşturan yönetişim mekanizmaları ve kentin kalkınma önceliklerinin, sorunlarının ve vizyonlarının sürdürülebilirlik ilkeleri temelinde belirlendiği, tartışıldı̆ğ ve çözümlerin 
geliştirildiği demokratik yapılar",

olarak tanımlanmıştır. 5393 sayılı Belediye Kanunu'na göre kent konseyinin, meslek kuruluşları; sendikalar; noterler; (varsa) üniversiteler; ilgili sivil toplum örgütleri; siyasi partiler; kamu kurum ve kuruluşları; mahalle muhtarlarının temsilcileri ve diğer ilgililerden (md.76/2) oluşması düzenlenmiştir.

Hemşehri hukukunun kurumsallaşmasını amaçlayan düzenlemeler arasında 2000'li yılların başlarında "Yerel Gündem 21" ismiyle gerçekleştirilen katılımcı yönetim modeli kent konseyi olarak uygulamaya aktarılmıştır (Keleş ve Mengi, 2017:84). Katılımcı demokrasi açısından öne çıkan ve ülkemizde çok sayıda belediyece uygulanan ve özellikle görüş bildirme ile görevlendirilen kurumsal yapılar olarak YG-21 Meclisleri (Karaman, 1998:240) 5393 sayılı Belediye Kanunu ile hukuki nitelik kazanmışlardır. Belediye Kanunundan önce ülkemizde YG-21 meclisleri ismiyle kurulan günümüzün Kent Konseyleri, yerel halkın tüm toplumsal kesimlerinin (yerel) karar süreçlerinde yer almasını sağlamak, kent mekân ölçeğinde danışma kurumu oluşturma hedefi ile düzenlenmiştir. Bahse konu hedefin kurumsallaşmasına yönelik konseylerin oluşumunda; sivil toplum kuruluşları (dernek, vakıf, sendika) başta olmak üzere meslek örgütleri, özel sektör kuruluşları ve mahalle muhtarları gibi yerel unsurlar kentsel sorunların çözümüne katkı sağlamak amacıyla danışma işlevi görmek üzere bir araya getirilmişlerdir.

Kent Konseylerinin öne çıkan temel işlevi, kent ölçeğindeki paydaşları kapsayacak biçimde "ortak akıl" geliştirilmesidir. YG-21 Meclisleri kapsamında (Emrealp, 2005:65);
"kentine sahip çıkma, aktif katılım ve çözümde ortaklık ilkeleri çerçevesinde kentleri sürdürülebilir geleceğe taşıyan bir ortaklık modeli olarak tanımlanan Kent Konseyleri, yerel düzeyde demokratik katılımın yaygınlaş̧tırılmasını, hemşehrilik bilincinin geliştirilmesini, çok-aktörlü ve çok-ortaklı yönetim tarzının benimsenmesini",

sağlama amaçları taşımaktadır. Belediyelere kent konseylerinin işlevsel kılınmasına yönelik görevler verilmektedir. Belediye Kanunun 76. maddesinde yer alan ilişki biçimlerinden biri belediyelerin kent konseyine destek olmasına ve yardımlarına yöneliktir ve belediyeler kent konseyinin faaliyetlerinin etkin yürütülmesi konusunda destek sağlamakla görevlidirler. İkinci ilişki konseyde alınan kararların belediye meclisine taşınmasıdır. $\mathrm{Bu}$ çerçevede Kanunun 76. maddesinde göre kent konseyinde oluşturulan görüşler belediye meclisinin ilk toplantısında gündeme alınacaktır (Öner, 2010:240). Öte yandan Kent konseyinin işlevleri arasında; "yönetişim eksenli katılımcı demokrasiyi hayata geçirmesi; kentin yaşam kalitesinin arttırılması için kentin hak ve hukukunun korunmasi; hemşehrilik bilincinin geliştirilmesi ve hemşehriler arasında sosyal yardımlaşma ve dayanışmayı geliştirmesi" (Çelik, 2013:216) başlıklarının sayılması bu kuruma yüklenen misyona güçlü bir işaret niteliği taşımaktadır.

Kent konseyleri, vatandaş isteklerini ve düşüncelerini göz önüne alarak ve yerel yönetimlerin faaliyetlerini halk ve merkezi yönetim arasında bağlantı kurarak gerçekleştirmeyi amaçlayan mekanizmalardır. Dolayısıyla kuruluş amaci; tamamen kentsel yaşam kalitesinin ve yerel demokrasinin gelişmesine katkı sağlamak olan bu mekanizmalara, kentleri sürdürülebilir insan yerleşkesine dönüş̧ürmede yaşamsal sorumluluklar yüklenmiştir (Kocaoğlu ve Sert, 2018:59). 8 Ekim 2006 tarihli Kent Konseyi Yönetmeliğinde Konseyin (www.resmigazete.gov.tr);

"yerellik ilkesi çerçevesinde katılımcıllı̆g, demokrasiyi ve uzlaşma kültürünü geliştirmek; Sivil toplumun gelişmesine ve kurumsallaşmasına katkıda bulunmak; Çocukların, gençlerin, kadınların ve engellilerin toplumsal yaşamdaki etkinliklerini arttırmak ve yerel karar alma mekanizmalarında aktif rol almalarını sağlamak vb.",

görevlerinin sayılmış olması konseyin demokratik ve katılımcılık perspektifine ait öngörülen misyonun işlerlik kazanmasına yönelik kurumsal desteği ifade etmektedir.

\subsubsection{Gönüllü Katılım}

Günümüzün sosyo-ekonomik, yönetimsel vb. değişimler yerel ölçekte yerel hizmetlerin üretimini ve sunumunu etkilemektedir. Yerel nitelikli hizmetlerin etkin, eşit, adil ve ihtiyaçlara uygun şekilde karşılanması hedefinin belediyelerin finans başta olmak üzere altyapılarının çoğunlukla elverişsiz oluşu yerel hizmetin tüm aşamalarında (üretim, erişim) alternatif yapı-model arayışlarına yol açmıştır. Bu noktada günümüzde gelişen hizmet taleplerine bağlı olarak yerel kurumların mal ve hizmetlerin sunumunu gereği şekilde sağlamanın yanında bunlara erişimi kolaylaştıran kurumsal araç konumuna gelme fonksiyonunu üstlenmek durumdadır. Yerel nitelikli hizmetlere erişim kolaylığı konusunda mevcut kurumsal yönetimlerin yanında toplumun sivil 
toplum ve özel sektör gibi diğer aktörlerinin ve tabi ki bireysel katkıların teşvik edilmesi, şekillenmesi ve koordine edilmesi gerekliliği ortaya çıkmıştır. Bu çerçevede şekillenen yerel hizmetlere gönüllü katılım; "bir beldede yerel yönetimlerce sunulan yerel nitelikli hizmetlere belde halkının, kendi isteğiyle örgütlenerek yapmış oldukları her türlü katkı ve katılım olarak" (Altın ve Şahin, 2019:104) tanımlanmaktadır. Yerel ölçekte bu konuda belediye yönetimlerine görevler verilmiştir. Kanunun 77. maddesine göre belediyeler;

"sağllk, eğitim, spor, çevre; sosyal hizmet ve yardım; kütüphane, park, trafik ve kültür hizmetleriyle; yaşlılara, kadın ve çocuklara, özürlülere, yoksul ve düşkünlere yönelik hizmetlerin yapılmasında beldede dayanışma ve katılımı sağlamak, hizmetlerde etkinlik, tasarruf ve verimliliği artırmak amacıyla gönüllü kişilerin katılımına yönelik programlar",

uygulayacaklardır. Bu konudaki düzenlemeler 2005'de yayınlanan İl Özel İdaresi ve Belediye Hizmetlerine Gönüllü Katılım Yönetmeliği yürürlüğe konulmuştur. Yönetmeliğin 4. maddesinde gönüllü kavramı;

"bilgi, beceri ve yeteneğini, her türlü ortak çalışma, imkân ve zamanını ortaya koyarak çalışma alanı konusunda maddi bir kazanç beklemeksizin yerel yönetim hizmetlerine katılan gerçek ve tüzel kişiler ile bünyesindeki gönüllüleri bu hizmetlerde görevlendirecek kamu kuruluşları",

olarak tanımlanmıştır. İlgili yönetmeliğin 8. maddesi gereği belediyeler;

"kendi özel kanunlarına uygun olarak aralarında yapacakları protokol çerçevesinde kamu kurum ve kuruluşları, kaти kurumu niteliğindeki meslek kuruluşları, dernekler, vakfflar, meslek odaları ve diğer yerel yönetim birimleri ile ortak çalışma ve işbirliği yapabilecekler".

Ayrıca, yine yönetmeliğe göre, "gönüllülerin katılımı ile yapılan hizmetlerden doğan sorumluluk ilgili belediyeye ait" (md.10) olacaktır.

\section{ON BİRINCI KALKINMA PLANINDA SIVIIL TOPLUM PERSPEKTIFI ${ }^{1}$}

1990'lardaki kalkınma politikası tartışmaları, belirgin bir şekilde, devletin daha küçük bir rolünü ve piyasa için daha güçlü bir rolü teşvik eden daha geniş hükümet politikası eğilimlerini yansıtan sivil toplum terimini öne çıkarmıştır. Pazar ve devlet arasındaki "sivil toplum" varlığının demokrasiyi hem güçlendirecek hem de teşvik edecek bir örgütlenme alanı sağlaması öngörülmüştür. NGO'lar, kalkınma politikasında sivil topluma yapılan bu daha güçlü vurguyu kendi kurumsal yapılarını yerleşik siyasi teori içine yerleştireceği ve rollerinin teorik gerekçesini/altyapısını sağlayacağı gerekçeleri ile memnuniyetle karşılamışlardır (Keijzer ve Bossuyt, 2020:785-786).

Tablo 2. STK'nın Araçsallaştırılması: Sektörel Roller

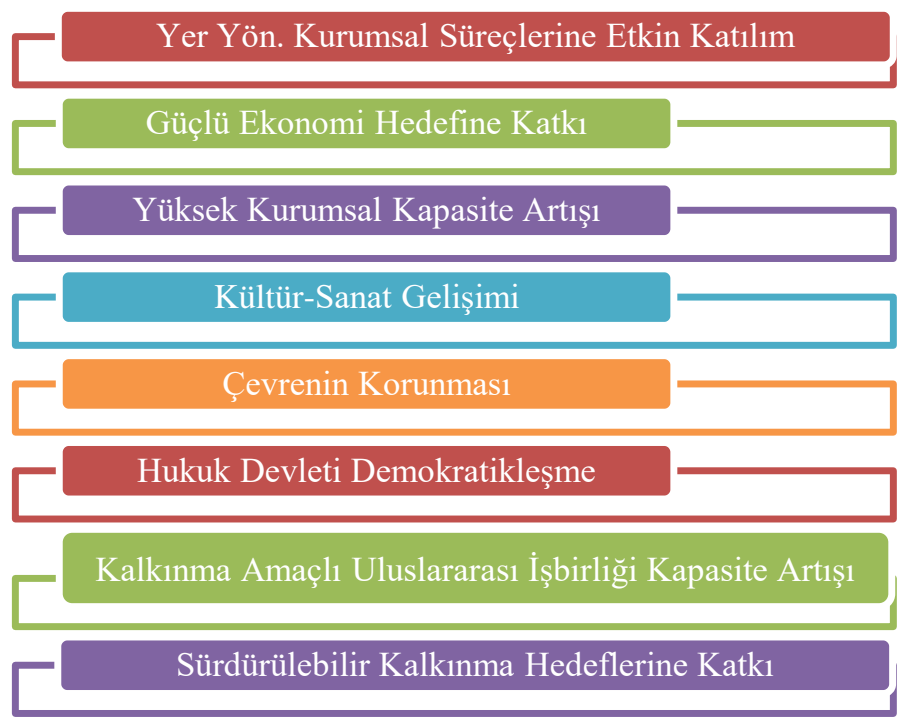

1 Çalışmanın bu kısmı; Bandırma Onyedi Eylül Üniversitesi tarafından 01-03 Kasım 2019'da Bandırmada düzenlenen X. Uluslararası Sivil Toplum Kuruluşları Kongresi Endüstri 4.0'dan Toplum 5.0'a Çalışmanın Geleceği STK'lar ve Sendikalar, adlı Kongrede sunulan "Sivil Toplum Algısı ve Öngörülen Kurumsal Roller Açısından Kalkınma Planlarının Dönemsel Analizi” adlı Tebliğin On Birinci Kalkınma Planı ile ilgili bölümünün gözden geçirilmiş ve güncellenmiş halinden oluşmaktadır. 
Türkiye Cumhuriyeti’nin On Birinci, (2018 yılında uygulamaya geçilen) Cumhurbaşkanlığı Hükümet Sisteminin ise Birinci Kalkınma Planı 23 Temmuz 2019'da Resmi Gazete'de yayınlanmıştır. Plan ile sivil toplum kuruluşlarına sadece ülke içinde değil uluslararası düzeyde kalkınma girişimlerinde roller verildiği üstelik ülkemizin tanıtımı açısından kurumsal misyonlar yüklenildiği görülmektedir (Tablo 2). Plan, "istikrarlı ve güçlü ekonomi, rekabetçi üretim ve verimlilik, nitelikli insan ve güçlü toplum, yaşanabilir şehirler ve sürdürülebilir çevre ile hukuk devleti, demokratikleşme ve iyi yönetişim" (www.sbb.gov.tr) olmak üzere beş ana gelişme ekseninden meydana gelmektedir.

\subsection{Temel Perspektifler Açısından Sivil Toplum ve Sivil Toplum Kuruluşları}

Planın hedef ve politikalarına yönelik olarak sivil toplum olgusu ve sivil toplum kuruluşlarına (STK) ilişkin amaç ve politikalar ayrı başlık altında ele alınmıştır. Sivil toplum konusunda öngörülen dört temel amaç şunlardır (www.sbb.gov.tr); "Sivil toplum bilincinin gelişmesi; Örgütlü sivil toplumun güçlenmesi; STK'ların saydamlık ve hesap verebilirlik ilkelerine uygun bir yapıya kavuşması ve devletin karar alma süreçlerine etkin katılımının sağlanması"dır. Planın sivil toplum başlığı içinde belirlenmiş olan politika ve tedbirler şunlardır (www.sbb.gov.tr);

- Demokratik, çoğulcu, şeffaf, katılımcı ve hesap verebilir sivil toplumun oluşumuna yönelik iyileştirmelere gidilmesi

- Uluslararası standartlarda STK veri tabanı oluşturulması ve verilerin yayımlanması

- STK'ların kurumsal süreçlerinin şeffaflık ve hesap verebilirlik ilkeleri çerçevesinde yeniden düzenlenmesi

- STK'nın karar alma ve mevzuat hazırlama süreçlerine katılımlarını ilgili süreçlerde etkinliğini artıracak çalışmalar yapılması

- STK'nın idari ve mali alanlarda sürdürülebilirliklerine katkı sağlamaya yönelik düzenlemeler yapılması

- Sosyo-ekonomik faydayı arttırmaya yönelik olarak gerçek/tüzel kişilerin STK ilişkilerini teşvik ve kolaylaştıran finans/vergi düzenlemelerinin yeniden ele alınması

- Sivil toplum kuruluşları ile kamu kurumları işbirliğinin güçlendirilmesi; STK'nın kurumsal kapasitelerinin geliştirilmesi

- Sivil Toplumla İlişkiler Genel Müdürlügü̆’nün² kurumsal kapasitesinin görev alanıyla uyumlu şekilde güçlendirilmesi (www.siviltoplum.gov.tr) ${ }^{3}$

- STK'nın proje hazırlama, fon bulma vb. kapasite geliştirme eğitimlerinin yaygınlaştırılması

- Sivil toplum faaliyetlerine yönelik toplumsal farkındalığın arttırılması ve STK'nın toplumsal görünürlüklerinin geliştirilmesi

- Okullardaki uygulamalarla çocukların sivil toplum tanışması ve gönüllülük bilincinin oluşmasının sağlanması

- Üniversitelerde sivil topluma yönelik yapıların çoğaltılması ve Üniversitelerde sivil topluma yönelik sertifikasyon ve lisansüstü programların açılması

\subsection{STK'nın Kurumsal Roller Açısından Araçsallaştırılması}

Az önce ifade ettiğimiz gibi Planda sivil toplum olgusuna ve sivil toplum kuruluşlarının kurumsal yapılarına ilişkin değerlendirme ve vizyoner yaklaşımları ayrı bir başlık altında toplanmıştır. Bunun yanında plan başlık ve içerikleri incelendiğinde çeşitli konu başlıklarında da sivil toplum kuruluşlarına atıf yapıldığı görevlendirme öngörülerine rastlanmaktadır. Çalışmamızın bu kısmında Planda sivil topluma ilişkin gerçekleştirilen rol/görev belirlemeleri ve yaklaşımlar ele alınacaktır.

2 İçişleri Bakanlığı bünyesinde 03.08.2002 tarih ve 4771 sayılı Kanunun 46. maddesi ile kurulan "Dernekler Dairesi Başkanlığı", 13.09.2018 tarihli 17 nolu Cumhurbaşkanlığ Kararnamesi ile "Sivil Toplumla İlişkiler Genel Müdürlüğü"ne dönüştürülmüştür.

3 Sivil Toplumla İlişkiler Genel Müdürlüğü, 1 nolu Cumhurbaşkanlığı Teşkilatı Hakkında Cumhurbaşkanlığı Kararnamesinin 256. maddesi ile İçişleri Bakanlığı teşkilatı içinde yer almıştır (RG, Tarih: 10.07.2018 Sayı: 30474). 


\subsubsection{Ekonomik Hedefler ve STK}

Planın hedefleri ve politikalarının belirlenmesine yönelik istikrarlı ve güçlü ekonominin oluşturulmasında STK iki biçimde konumlandırılmış görülmektedir. Birincisi; makro-ekonomik politikalar belirlenmesine yönelik "temel dönüşüm kararlarında (kamu, özel sektör) STK ve diğer bütün paydaşların katılımlarıyla toplumsal mutabakatın oluşturulmasına özel önem verilmesi" (www.sbb.gov.tr). İkincisi; "Et ve Süt Kombinalarındaki atıl kapasitenin (kamu ve özel sektör ile) STK'lar tarafindan kullanılmasının sağlanması” (www.sbb.gov.tr) öngörülmüştür.

\subsubsection{Kurumsal Kapasite ve STK}

Planın hedef ve politikalarından biri olan rekabetçi üretim ve verimliliği sağlamak için öngörülen yatay politika alanlarından biri yüksek kurumsal kapasite olarak belirlenmiştir (www.sbb.gov.tr). Özel sektörün kurumsal kapasitesinin geliştirilmesine yönelik belirlenen politikalar arasında STK'na verilen roller şu başlıklar altında toplanabilir (www.sbb.gov.tr);

- Meslek kuruluşları ile imalat sektöründeki STK'larının mevcut sorunlara çözüm üretecek yapıya kavuşmalarının desteklenmesi

- İmalat sektörlerindeki STK'nı içeren kapasite gelişim programı uygulanması

- STK'nın sektörel sorunlara yönelik projelerinin desteklenmesi

\subsection{3. Çevrenin Korunması ve STK}

Yaşanabilir şehirler ve sürdürülebilir çevre başlı̆̆ içinde yer verilen çevre koruma konusunda planda; "çevre ve doğal kaynakların korunması, kalitesinin iyileştirilmesi, etkin, entegre ve sürdürülebilir şekilde yönetiminin sağlanması, her alanda çevre ve iklim dostu uygulamaların gerçekleştirilmesi, toplumun her kesiminin çevre bilinci ile duyarlılığının artırılması" (www.sbb.gov.tr) temel amaç olarak belirlenmiştir. Çevre konusunda öngörülen politika içeriklerinde çevre ile ilgili kuruluşların görev-yetki ve sorumluluklarının netleştirilmesi kamu ve özel sektörün yanı sıra yerel yönetimler ve STK arasında işbirliğinin geliştirilmesi ayrıca toplumsal kesimlerin çevre bilincinin artırılması tüm bu politikalar çerçevesinde etkin çevre yönetiminin sağlanması öngörülmektedir.

\subsubsection{Hukuk Devleti Demokratikleşme ve STK}

Planda ekonomik ve sosyal kalkınmanın temel ortağı haline gelen STK'larının dinamik ve esnek yapıya kavuşma gereğine vurgu yapılmaktadır. Bu özelliklere sahip STK'nın yerel/ulusal talep ve sorunlara cevap verebilme potansiyelinden yararlanılması da ayrı bir önem taşımaktadır. STK'nın üstleneceği rollerin demokrasinin niteliğinin geliştirilmesinin yanında kamu yönetimince sunulan hizmetlerin kalifikasyonunun artırılmasına da katkı yapması öngörülmektedir. Plan döneminde "aktif vatandaşlık bilincinin gelişstirilmesi, karar alma süreçlerine STK’nın etkin katılımının sağlanması, sivil toplum- kamu-özel sektör işbirliğinin artırlması ve sosyal diyalog ortamının geliştirilmesi, STK'nın kurumsal, beşeri ve finansal kapasitelerinin güçlendirilmesi" (www.sbb.gov.tr) hedeflenmektedir.

\subsubsection{Kalkınma Amaçlı Uluslararası İşbirliği Çerçevesinde Ulusal Kapasite ve STK}

Planda ülkemizin diğer ülkeler nezdindeki uluslararası kalkınma işbirliği girişimlerinin stratejik yaklaşımla, daha etkin ve koordinasyon içerisinde yürütülmesi temel amaç olarak belirlenmiştir (www.sbb.gov.tr). Bu konuda ortaya konulan politika araçları ve tedbirler arasında STK'na roller verilmekle birlikte, STK'nın üstlenmesi öngörülen rollere ilişkin olarak işbirliği, koordinasyon ve yapabilirlik kapasitelerine ilişkin atıflar yer almaktadır. Bu konuda planın politika araçları ve öngördüğü tedbirler kısaca şunlardır (www.sbb.gov.tr):

“Kamu, özel sektör ve STK’nın diğer ülkelere yönelik kalkınma yardımlarının organizasyonunda eşgüdüm sağlanması; STK tarafindan uluslararası düzeyde gerçekleştirilecek yardım faaliyetlerinin stratejik perspektifle ele alınması; STK'nın uluslararast yardım girişimlerinin kamu 
kurumları ile koordinasyon içerisinde yürütülmesinin sağlanması; STK tarafindan yapılan uluslararası kalkınma yardımı verilerinin toplanması ve raporlanmasına ilişkin mevzuatın güncellenmesi; STK'nın uluslararası kalkınma işbirliği faaliyetlerine yönelik akreditasyon kriterleri belirlenmesi; Uluslararası kuruluşlar, yabancı yardım kuruluşları, yabancı diplomatik misyonlar ve uluslararası STK'ları gibi kalkınma işbirliği alanındaki tüm aktörlerin Türkiye'de yürüttükleri faaliyetlerin ülkemizin ulusal politikalarıyla uyumuna ilişkin işbirliği mekanizması oluşturulması".

\subsubsection{Sürdürülebilir Kalkınma Amaçları ve STK}

Planın dünyanın temel gündemlerinden birini oluşturan sürdürülebilir kalkınma konusunda düşünsel ve kurumsal bazlı öngörüsü bulunmaktadır. Bu çerçevede "sürdürülebilir kalkınma amaçlarının önceliklerimiz doğrultusunda politikalara yansitılması, amaçlara ilişkin etkili bir takip ve gözden geçirme mekanizması oluşturulması" (www.sbb.gov.tr) hedefi planda yer almıştır. Planda sürdürülebilir kalkınma amaçları başlığının yeri incelendiğinde "bir bölüm olarak çalışmanın son iki sayfasında değerlendirmeye alındiğı ve bu hedeflere dair bir amaç maddesi ve yaklaşık altı maddelik bir politika ve tedbirler bölümünün yer aldiğı görülüyor, buradaki ayrılık aslında amaçların planın tamamından ayrık konumunu göstermektedir" (Orhan, 2019:2). Bu konuda öngörülen temel politika ve tedbir olarak Cumhurbaşkanlığı bünyesinde "Ulusal Sürdürülebilir Kalkınma Koordinasyon Kurulu"'nun kurulmasıdır. Kurulun katılımcıları arasında (ilgili kamu kuruluşları, mahalli idareler, üniversiteler, özel sektör ile birlikte) STK'nın yer alması öngörülmüştür. Bu çerçevede STK'na Ulusal Sürdürülebilir Kalkınma Koordinasyon Kurulu bünyesinde; sürdürülebilir kalkınma amaçlarının uygulanmasının ulusal düzeyde takip ve gözden geçirilmesi ile koordinasyonunu sağlama rolü (www.idemahaber.com) verilmektedir.

\section{SONUÇ}

Yerelden ulusal, bölgesel ve uluslararası düzeylere kadar faaliyet gösteren, kentsel ve kırsal, resmi ve gayri resmi kuruluşlardan oluşan sivil toplum kuruluşları (Keijzer ve Bossuyt, 2020:788) nitelikleri itibariyle toplum kesimlerin artan ve çeşitlenen taleplerinin yansıması olarak yönetsel mekanizmalarda güçlü şekilde yer almaya başlamışlardır. Çalışmamızda ülkemizde yirminci yüzyılın son on yıllarında güçlü yasal ve kurumsal sonuçlarının yaşandığı sivil toplum-yönetim ilişki ve işbirliği belediye kuruluşları ekseninde ele alınmıştır. 2004 yılında büyük oranda değişikliğe uğrayan belediye mevzuatının belediye sivil toplum ilişkisi ve işbirliğine daha geniş bir bakış açısı getirdiğini söylemek mümkündür. Hatta bu bakışı yansıtan biçimde belediye mevzuatı literatürde "hemşehri odaklı yönetim modeli" olarak da tanımlanmıştır. Bu retoriği haklı çıkaracak düzenlemeler ise çalışmamızda üç başlıkta derlenmiş bulunmaktadır: Hemşehri Hukuku, Kent Konseyi ve Gönüllü Katılım.

Belediye mevzuatında herkes, "ikamet ettiği beldenin hemşehrisi” olarak tanımlanmış ve ayrıca sivil toplum kuruluşlarına ilişkin şu düzenlemelere yer verilmiştir: Belediye meclislerine katılma; belediyenin sosyo-kültürel çalışmalarında yer alabilme; kent konseyine iştirak etme; konuyla ilgili STK'nın belediye ihtisas komisyonlarında görüş bildirebilme vb. Bu noktada akla gelen soru ve/veya sorun; temel ve tamamlayıcı yerel mevzuat ile tanınan söz konusu hakların kullanımı noktasında sivil toplumun mevcut kapasite, imkân ve kabiliyetlerinin düzeyinin ne olduğudur. Bu noktada On Birinci Planda STK'na kamu ve özel sektör ile birlikte sosyo-ekonomik kalkınmanın temel paydaşları arasında yer verilmiş, bu kuruluşların idari ve mali açıdan şeffaf ve hesap verebilir hale getirilmesi yönünde öngörülere yer verilmiştir.

Çalışmamıza esas teşkil eden metinler üzerindeki incelememiz sırasında elde ettiğimiz ve metinde yer verdiğimiz tespitlere ek olarak etkin bir sivil toplum mekanizmasının aktif paydaş kılınabilmesine yönelik bazı önerilerimizi şu başlıklar altında toplayabiliriz: toplumsal kesimlerde sivil toplum algısı ve farkındalığı güçlendirilmelidir; sivil toplum kuruluşlarının toplumsal itibarına ve kabul edilişlerine zarar verecek kurumsal müdahalelerden kaçınılmalıdır; toplumsal sorunlara duyarlı ve proaktif bireylerin yetiştirilmesi sürecinde sivil toplum kuruluşlarının her aşamadaki eğitim kurumları ve öğrenciler ile etkin irtibat kurmalarının önü açılmalı ve desteklenmelidir; üniversitelerin ilgili bölümleri ile sivil toplum kuruluşları arasında etkili iletişim ve işbirliği fırsatları geliştirilmelidir; hemşehrilerin yaşadıkları kente ve yaşam alanlarına dair sorunları; kahvehane sohbetlerinde pazar yerinde ve sokak başlarında kendi aralarında "kısık sesle söylenerek" değil "açık yüreklilikle seslendirerek" katkı sağlayacakları kurumsal mekanizmalar geliştirilmelidir; demokratik, katılımcı ve çoğulcu toplumun önünde zihinsel kalıpların aşılmasına yönelik toplumsal bütünlüğün ve birlikteliğin sürdürülebilirliğini teşvik eden, destekleyen müstakil ve bütüncül bir sivil toplum mevzuatı hazırlanmalıdır. 


\section{KAYNAKÇA}

ALTIN, Aytuğ ve ŞAHIN, Erdal Osman (2019), "Yerel Yönetimlerde Alternatif Hizmet Sunma Yöntemi Olarak Yerel Hizmetlere Gönüllü Katılım”, Avrasya Sosyal ve Ekonomi Araştırmaları Dergisi (ASEAD), S.6(3), ss.89-114.

ASLAN, Seyfettin (2010), "Sivil Toplum: Kavramsal Değişsim ve Dönüşüm”, Elektronik Sosyal Bilimler Dergisi, S.9(33), ss.188-212.

ATAR, Yavuz (1997), "Demokratik Sistemde Sivil Toplumun Fonksiyonu ve Sivil Toplum-Devlet Düalizmi”, Yeni Türkiye, S.4(18), ss.98-122.

BEKTAŞ, Serkan (2019), "Katılımcı Kent Konseyi Modeli”, Ege Sosyal Bilimler Dergisi, S.2(2), ss.76-91.

CUMHURBAŞKANLIĞI STRATEJI VE BÜTÇE BAŞKANLIĞI (2019), On Birinci Kalkınma Planı, 23.07.2019 tarih ve (mükerrer) 30840 sayılı Resmi Gazete (Erişim Tarihi: 24.07.2019), http://www.sbb.gov.tr/wp-content/uploads/2019/11/ON_BIRINCI_KALKINMAPLANI_2019-2023.pdf

ÇAHA, Ömer (1997), “1980 Sonrası Türkiye'sinde Sivil Toplum Araylşları”, Yeni Türkiye Dergisi, S.4(18), ss.29-41.

ÇELIK, Abdullah (2013), "Kent Yönetimi Bağlamında Kent Konseyinin İşlevleri Üzerine Bir Değerlendirme”, C.Ü. İktisadi ve İdari Bilimler Dergisi, S.14(2), ss.215-229.

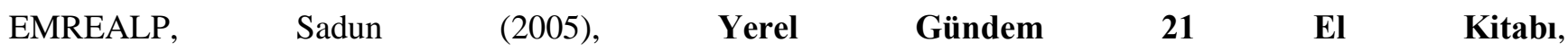
https://kentkonseyi.umraniye.bel.tr/userfiles/files/kentkonseyi/YG21-el-kitabi.pdf (Erişim Tarihi: 04.02.2020).

GÖNENÇ, Akpınar Ayşenur (2001), Sivil Toplum Düşünsel Temelleri ve Türkiye Perspektifi (E-Kitap), Altkitap Yayınları, İstanbul.

GREADY, Paul ve ROBINS, Simon (2017), "Rethinking Civil Society And Transitional Justice: Lessons From Social Movements And 'New' Civil Society", The International Journal of Human Rights, S.21(7), ss.956-975, https://www.tandfonline.com/doi/pdf/10.1080/13642987.2017.1313237?needAccess=true (Erişim Tarihi: 16.05.2020).

HALİFEOĞLU, Melek ve YETiș, Mehmet (2013), "Gramsci, Sivil Toplum - Devlet İkiliği ve Kuramsal Kökenler”, Mülkiye Dergisi, S.37(1), ss.163-187.

İBRAHIM, Ferhat (1997), "Sivil Toplum Üzerine Arap Tartışması”, Ortadoğu'da Sivil Toplumun Sorunları (Ed. Ferhat İbrahim, Heidi Wedel), İletişim Yayınları, İstanbul, ss.32-43.

İÇIŞLERİ BAKANLIĞI (2018), İçişleri Bakanlığı Sivil Toplumla İlișkiler Genel Müdürlüğü Kurumsal Web Sayfası, https://www.siviltoplum.gov.tr/sivil-toplumla-iliskiler-genel-mudurlugu (Erişim Tarihi: 23.09.2019).

IDEMAHABER (2019), "Ulusal Sürdürülebilir Kalkanma Koordinasyon Kurulu Kuruluyor", Idemahaber, 10.08.2019, http://www.idemahaber.com/ulusal-surdurulebilir-kalkinma-koordinasyon-kurulu-kuruluyor/ (Erişim Tarihi: 27.10.2019).

KARAMAN, Zerrin (1998), Kent Yönetimi ve Politikası, DEÜ Yayınları, İzmir, 4. Baskı.

KALM, Sara, STRÖMBOM, Lisa ve UHLIN, Anders (2019), "Civil Society Democratising Global Governance? Potentials and Limitations of CounterDemocracy”, Global Society, S.33(4), ss.499-519, https://www.tandfonline.com/doi/full/10.1080/13600826.2019.1640189 (Erişim Tarihi: 06.12.2019).

KEIJZER, Niels ve BOSSUYT, Fabienne (2020), "Partnership on Paper, Pragmatism on The Ground: The European Union's Engagement With Civil Society Organisations", Development in Practice, S.30(6), ss.784-794, https://www.tandfonline.com/doi/pdf/10.1080/09614524.2020.1801589?needAccess=true (Erişim Tarihi:16.05.2020).

KELEŞ, Ruşen, GÜNER, Ayşe ve ÖNER, Şerif (2009), “Yerel Yönetimlerde Katılım”, Batı Akdeniz Mimarlık Dergisi, S.15(42), Mimarlar Odası Antalya Şubesi Yayını, Antalya, ss.4-24.

KELEŞ, Ruşen ve MENGİ, Ayşegül (2017), Kent Hukuku, İmge Yayınları, Ankara. 
KOCAOĞLU, Mustafa ve SERT, Suzan (2018), "Kentsel Sürdürülebilirlik Kavramı ve Kentsel Sürdürülebilirliğin Sağlanmasında Kent Konseylerinin Rolü Üzerine Bir Değerlendirme”, Strategic Public Management Journal, S.4(8), ss.52-61.

KUMAR, Krishan (2008), “Civil Society, Globalization, and Global Civil Society”, Journal of Civil Society, S.4(1), ss.15-30, https://www.tandfonline.com/doi/pdf/10.1080/17448680802049562?casa_token=Fe_K_WPvgEAAAAA:3AtOATkYu8xVnsL1QQIhGmjbTofaU2g9NNpkgf3DJR_cuTyEt3YL123I83OVpo6zD bykCgCAUqdiKig (Erişim Tarihi: 16.05.2020).

ORHAN, Gökhan (2019), "11. Kalkınma Planı ve Sürdürülebilir Kalkınma Amaçları", EKOIQ, http://ekoiq.com/2019/10/03/11-kalkinma-plani-ve-surdurulebilir-kalkinma-amaclari/ (Erişim Tarihi: 27.10.2019).

ÖNER, Şerif (1998), “Cumhuriyetten Günümüze Demokratik Yerel Yönetim Anlayışının Gelişimi”, Yeni Türkiye, S.5(23-24), ss.3713-3728.

ÖNER, Şerif (2000), “Belediye Yönetim Kararlarında Sivil toplum Kuruluşlarının Etkinliği”, Yayınlanmamış Doktora Tezi, Dokuz Eylül Üniversitesi Sosyal Bilimler Enstitüsü, İzmir.

ÖNER, Şerif (2001), "Sivil Toplum Kuruluşlarının Yerel Demokrasi ve Katılım Algılamaları”, Çağdaş Yerel Yönetimler Dergisi, S.10(2), ss.51-67.

ÖNER, Şerif (2010), “Küresel Yönetim Anlayışının Türkiye'de Yerel Yönetimler Üzerindeki Yasal ve Kurumsal Etkileri”, Tartışılan Boyutlarıyla Küreselleşme (Ed. Osman Tekir, Şerif Öner), Gazi Kitabevi, Ankara, ss.227-252.

RICHARDSON, Jeremy J. (1993), Pressure Groups and Government (Ed. Jeremy J. Richardson), Oxford University Press, New York.

SAN, Coşkun (1994), “Demokratik Siyasal Kültür ve İnsan Hakları”, İnsan Hakları Yıllığı, S.16(3), ss.4-16.

SARIBAY, Ali Yaşar (1995), Postmodernite Sivil Toplum ve İslam, İletişim Yayınları, İstanbul, 2. Bask1.

TANDIRCIOĞLU, Haluk ve ÖNER, Şerif (2014), “6360 Sayıl Kanunun Mali Paylaşım Çerçevesinde Değerlendirilmesi”, Mali Yerinden Yönetim (Ed. Mustafa Sakal, Ahmet Kesik, Tekin Akdemir), Nobel Yayınları, Ankara, ss.247-264.

TUIK (2020), 2019 Yılı Adrese Dayalı Nüfus Kayıt Sistemi Sonuçları, TUíK Yayını, Ankara, http://www.tuik.gov.tr/HbGetirHTML.do?id=33705 (Erişim Tarihi: 04.02.2020).

UKESSAYS (2018), "The Concept of Civil Society Politics Essay", UKEssays, https://www.ukessays.com/essays/politics/the-concept-of-the-civil-society-politics-essay.php (Erişim Tarihi: 06.12.2019).

UKESSAYS (2018), "The Stronger Civil Society The Stronger Democracy Politics Essay", UKEssays, www.ukessays.com/essays/politics/the-stronger-civil-society-the-stronger-democracy-politics-essay.php (Erişim Tarihi: 06.12.2019).

VANDYCK, Charles Kojo (2017), “Concept and Definition of Civil Society Sustainability”, CSIC - Center For Strategic \& International Studies, www.csis.org/analysis/concept-and-definition-civil-societysustainability (Erişim Tarihi: 06.12.2019).

YENIŞEHIRLIOĞLU, Şahin (1995), Birey Toplum Devlet İlişkileri, Ümit Yayıncıllk, Ankara, 2. Bask1.

YILMAZ, Aytekin (1997), “Sivil Toplum Demokrasi ve Türkiye”, Yeni Türkiye Dergisi, S.3(18), ss.83-93.

1 Nolu Cumhurbaşkanlığı Kararnamesi (10.07.2018 tarih ve 30474 sayılı Resmi Gazete).

13 Nolu Strateji ve Bütçe Başkanlığı Teşkilatı Hakkında Cumhurbaşkanlığı Kararnamesi (24.07.2018 tarih ve 30488 sayıli Resmi Gazete).

17 Nolu Cumhurbaşkanlığı Kararnamesi (13.09.2018 tarih ve 30534 sayılı Resmi Gazete).

İl Özel İdaresi ve Belediye Hizmetlerine Gönüllü Katılım Yönetmeliği (09.10.2005 tarih ve 25961 sayılı Resmi Gazete).

Kent Konseyi Yönetmeliği (08.10.2006 tarih ve 26313 say1lı Resmi Gazete). 